\title{
Evaluation of Organic-Based Fertilizers for Corn Production in the Marginal Uplands of Inopacan Leyte
}

\author{
Berta C. Ratilla', Sataki P.Toledo ${ }^{2}$ and Othello B. Capuno ${ }^{3}$ \\ ${ }^{1}$ Visayas State University, Department of Agronomy and Soil Science, Visca, Baybay \\ City, Leyte, ${ }^{2}$ Visayas State University, Visca, Baybay City, Leyte, ${ }^{3}$ Office of the Vice \\ President for Research and Extension, Visayas State University, Visca, Baybay City, \\ Leyte, Philippines
}

\begin{abstract}
Marginal uplands have low crop productivity due to poor soil fertility and continuous degradation. The study evaluated the effects of various organicbased fertilizers on the growth and yield performance of corn; determine the appropriate combination of organic and inorganic fertilizers for optimum corn yield; and assess changes in soil properties. The experiment was laid out in Randomized Complete Block Design (RCBD) in three replications with seven treatments: $\mathrm{T}_{0}=(0-0-0) ; \mathrm{T}_{1}=1$ tha $^{-1}$ evans $+45-30-30 \mathrm{~kg} \mathrm{~N}, \mathrm{P}_{2} \mathrm{O}_{5}, \mathrm{~K}_{2} \mathrm{Oha}^{-1} ; \mathrm{T}_{2}=1 \mathrm{t}$ ha $^{-1}$ wellgrow $+45-30-30 \mathrm{~kg} \mathrm{~N}, \mathrm{P}_{2} \mathrm{O}_{5}, \mathrm{~K}_{2} \mathrm{O} \mathrm{ha}^{-1} ; \mathrm{T}_{3}=15$ t ha $^{-1}$ chicken litter; $\mathrm{T}_{4}=10 \mathrm{t}$ ha $^{-1}$ chicken litter $+45-30-30 \mathrm{~kg} \mathrm{~N}_{2} \mathrm{P}_{2} \mathrm{O}_{5}, \mathrm{~K}_{2} \mathrm{O}_{\text {ha }}{ }^{-1} ; \mathrm{T}_{5}=15 \mathrm{t} \mathrm{ha}^{-1}$ vermicast; and $\mathrm{T}_{6}$ $=10$ tha $^{-1}$ vermicast $+45-30-30 \mathrm{~kg} \mathrm{~N}_{2} \mathrm{P}_{2} \mathrm{O}_{5}, \mathrm{~K}_{2} \mathrm{O} \mathrm{ha}^{-1}$.

Most agronomic characters as well as yield and yield components of corn were significantly affected by the treatments. Application of $10 \mathrm{t} \mathrm{ha}^{-1}$ chicken litter $+45-30-30 \mathrm{~kg} \mathrm{~N}, \mathrm{P}_{2} \mathrm{O}_{5}, \mathrm{~K}_{2} \mathrm{O}$ ha $^{-1}$ markedly enhanced height, leaf area index and stover yield of corn comparable with $10 \mathrm{t} \mathrm{ha}^{-1}$ Vermicast $+45-30-30 \mathrm{~kg} \mathrm{~N}$, $\mathrm{P}_{2} \mathrm{O}_{5}, \mathrm{~K}_{2} \mathrm{O}$ ha $^{-1}$. This treatment produced significantly higher grain yield in two croppings due to bigger ears and heavier seed weight over the untreated control and appeared the most promising combination. No remarkable changes in soil properties were noted except for an increase in available P and exchangeable K. Supplementation of organic with inorganic fertilizers is necessary to enhance productivity of marginal uplands.
\end{abstract}

Keywords: marginal uplands, chicken litter, evans, wellgrow, vermicast, inorganic fertilizers.

Correspondence : B.C. Ratilla Address: Department of Agronomy and Soil Science, Visayas State University, Baybay City, Leyte, 6521-A PhilippinesEmail: bcratilla61@gmail.com DOI: $10.32945 /$ atr36s7.2014 


\section{INTRODUCTION}

Corn (Zea mays Linn) widely known as maize, is one of the most important agricultural crops in the country. In times of food scarcity, this crop is a very good substitute or supplement for rice. It is considered as staple cereal especially in Mindanao and Visayas regions, utilized as feeds for poultry and livestock and used for industrial purposes. The high demand of this crop therefore calls for appropriate management strategies especially when grown in unproductive soils.

Marginal uplands are still being used for corn production despite low crop productivity due to poor soil fertility, continuous degradation and vulnerability to climatic changes. Often corn production is partly improved with the application of agrochemicals including inorganic fertilizers and pesticides. However, with the increasing cost of inorganic fertilizers and its known risks to soil, environment and consumers, there is a need for alternative organic-based inputs which are environmentfriendly, locally available and can improve soil properties. Aguilera et al. (2013) stated that unlike synthetic fertilizers, organic nutrient sources increase the organic matter content of the soil and help in waste management aside from mitigating climatic changes as it can reduce $\mathrm{N}_{2} \mathrm{O}$ emissions.

Organic farming is a form of organic agriculture that uses organic inputs to supply nutrients and manage pests and diseases (Perumal et al. 2006). It involves a set of management practices which are environmentfriendly, and can promote sustainable biological productivity, plant growth and animal health (Mazzoncini et al. 2010). It is a popular strategy to help address climatic changes (Sciallaba and Lindenlauf, 2010; Muller 2009) and degraded soils in marginal uplands. This study was conducted in support of Republic Act 10068 in the country otherwise known as Organic Agriculture Act of 2010. The law aims to maintain and improve soil productivity and produce safe and nutritious crops.

Several claims on the ill-effects and hazard of excessive and continuous use of inorganic fertilizers on soil, environment and crops are widespread, hence the shift to organic farming. The continuous price hike of inorganic inputs and fuel nowadays also made it difficult for resource-poor farmers to buy them. Thus, with locally available organic nutrient sources, the use of these materials can be greatly facilitated due to minimal transport and hauling cost. Despite their low nutrient content, these organic inputs can improve the chemical, physical and biological properties of the soil and 
maintain environmental quality (Mamaril and Castillo, 2009). These can help build soil organic matter which can improve soil structure and promote balance of pore size distribution thus improves water infiltration, drainage, water holding and cation exchange capacities (Cosico 2005; LEISA 2008; Sciallaba and Lindenlauf, 2010).

A number of organic-based fertilizers are available nowadays in the market or in the locality as alternative source of nutrients for crop growth and development. It is for this reason that this study was conducted to evaluate the efficacy of these commercially and locally available organicbased fertilizers on corn under the prevailing soil and climatic conditions of Eastern Visayas. Combining these organic fertilizer materials with inorganic fertilizers was done to provide a ready source of nutrients for the crop which according to Quimbo et al. (2014) is an effective way to sustain soil fertility. Specifically, this study aimed to evaluate the effects of various organic fertilizer sources applied alone or in combination with inorganic fertilizers on the growth and yield of corn, determine the appropriate combination of organic and inorganic fertilizer that will give optimum yield of corn, and assess their effects on the physical and chemical condition of the soil.

\section{MATERIALS AND METHODS}

\section{Description of the Study Site}

This study was conducted in Sitio Batuan, Bgy. Linao, Inopacan, Leyte, for two croppings (dry and wet seasons) in a gently sloping area with about $7 \%$ slope. The soil type was clay loam having a $4.8 \mathrm{pH}, 1.67 \%$ organic carbon, $0.21 \%$ total $\mathrm{N}, 0.74 \mathrm{mg} \mathrm{P} \mathrm{kg}^{-1}$ soil and $81.58 \mathrm{mg} \mathrm{K} \mathrm{kg}^{-1}$ soil. According to Landon (1991) the soil is very strongly acidic, has low organic matter, nitrogen and extractable potassium and very low phosphorus contents. Imperata cylindrica, Saccharum spontaneum and Melastoma sp. were the dominant vegetations in the area that it required several passing of land preparation activities.

\section{Land Preparation, Soil Sampling and Analysis}

The area was prepared by about five (5) plowings and three (3) harrowing operations after which furrows were constructed at a distance of $0.75 \mathrm{~m}$. Prior to plowing, soil samples were collected using a core 
Ratilla et al.

sampler for the initial bulk density determination. These samples were oven dried at $105^{\circ} \mathrm{C}$ for about 72 hours, weighed and their bulk density computed using the formula:

$$
\mathrm{D}_{\mathrm{b}}=\frac{M s}{V t}
$$

where:

$$
\begin{aligned}
& M_{s}=\text { Mass of soil (final oven dry weight) } \\
& V_{t}=\prod r^{2} h ; \text { where: } \Pi=3.1416 ; \\
& r=\text { radius } \\
& h=\text { height of the core }
\end{aligned}
$$

Another set of soil samples were also randomly collected from the experimental site at a depth of $0-20 \mathrm{~cm}$. These were composited, air dried, sieved ( $2 \mathrm{~mm}$ wire mesh) and analyzed for soil $\mathrm{pH}$ (potentiometric method at 1:2.5 soil water ratio), organic Carbon (modified Walkley-Black method), total $\mathrm{N}$ (modified Kjeldahl method), available phosphorous (modified Olsen's method) and exchangeable $\mathrm{K}$ (ammonium acetate method pH 7.0 for extraction and quantified using Varian 220 FS Atomic Absorption Spectrometer) at the Central Analytical Services Laboratory (CASL) of PhilRootcrops, Visayas State University. For final analysis, soil samples were taken from each treatment plot and analyzed for the same aforementioned parameters.

\section{Experimental Design and Treatments}

The experiment was laid out in randomized complete block design (RCBD) with three replications. Each plot measured $4.5 \mathrm{~m}$ x $4.5 \mathrm{~m}(20.25$ $\mathrm{m}^{2}$ ) with 6 rows per plot. Alleyways of $1 \mathrm{~m}$ between replications and $0.5 \mathrm{~m}$ between treatments were provided to facilitate farm operations and management as well as data gathering. Four organic fertilizers such as Evans, Wellgrow, Chicken litter and Vermicast were tested either alone or in combination with inorganic fertilizers. The treatments were designated as follows: $\mathrm{T}_{0}=(0-0-0) ; \mathrm{T}_{1}=1$ tha $^{-1}$ evans $+30-30-30 \mathrm{~kg} \mathrm{~N}, \mathrm{P}_{2} \mathrm{O}_{5}, \mathrm{~K}_{2} \mathrm{O}$ ha $^{-1} ; \mathrm{T}_{2}=$ 1 t ha ${ }^{-1}$ wellgrow $+30-30-30 \mathrm{~kg} \mathrm{~N}, \mathrm{P}_{2} \mathrm{O}_{5}, \mathrm{~K}_{2} \mathrm{O} \mathrm{ha}^{-1} ; \mathrm{T}_{3}=15 \mathrm{t} \mathrm{ha}^{-1}$ chicken litter; $\mathrm{T}_{4}=10 \mathrm{t} \mathrm{ha}^{-1}$ chicken litter $+45-30-30 \mathrm{~kg} \mathrm{~N}, \mathrm{P}_{2} \mathrm{O}_{5}, \mathrm{~K}_{2} \mathrm{O}$ ha $^{-1} ; \mathrm{T}_{5}=15 \mathrm{t} \mathrm{ha}^{-1}$ vermicast; and $\mathrm{T}_{6}=10$ tha $^{-1}$ vermicast $+45-30-30 \mathrm{~kg} \mathrm{~N}, \mathrm{P}_{2} \mathrm{O}_{5}, \mathrm{~K}_{2} \mathrm{O}^{-1} \mathrm{ha}^{-1}$. In the second cropping (wet season), the same treatments were employed except that for $\mathrm{T}_{1}$ and $\mathrm{T}_{2}$, the supplemental amount of inorganic $\mathrm{N}$ was raised to 45 $\mathrm{kg} \mathrm{ha}^{-1}$. Organic fertilizers were applied basally in furrows at the rates specified in the treatments prior to planting. For the inorganic 
supplements, complete fertilizer at the rate of 30-30-30 $\mathrm{kg} \mathrm{N} \mathrm{P}_{2} \mathrm{O}_{5}, \mathrm{~K}_{2} \mathrm{O} \mathrm{ha}^{-1}$ was also applied basally prior to planting. The remaining $15 \mathrm{~kg}$ of $\mathrm{N}$ was applied 1 month after planting corn using urea (45-0-0).

\section{Planting, Replanting and other Management Practices}

Corn seeds (IPB Var. 6) were sown in furrows at a distance of $0.75 \mathrm{~m}$ between rows and $0.50 \mathrm{~m}$ between hills at 2 to 3 seeds/hill. Thinning to 2 plants per hill was done one week after sowing while replanting was also done to missing hills to meet the desired plant population of 53,333 plants $\mathrm{ha}^{-1}$. Weeds were controlled by hand weeding. Hilling up was done manually in each treatment plot for better stability and anchorage of plants. Plants were watered during the first cropping (dry season) especially during the early stages of growth due to absence or very limited rain (Table 1). Harvesting was done when the corn plants had reached maturity as indicated by the change in color of the husks and leaves from green to brown, the grains becoming firm, clear and with black layer in kernel scutellum. Only plants from the four inner rows excluding end hills were harvested. Harvested corn ears were dehusked, shelled and the grains sun-dried to about $14 \%$ moisture content before gathering the subsequent data.

\section{Data Gathered}

The data gathered for corn included agronomic characters such as number of days from seeding to tasseling, silking and maturity, plant height $(\mathrm{cm})$, leaf area index (LAI), and fresh stover yield $\left(\mathrm{t} \mathrm{ha}{ }^{-1}\right)$; yield and yield components including ear length $(\mathrm{cm})$, ear diameter $(\mathrm{cm})$, weight of 1000 seeds(g) and grain yield ( $\left.\mathrm{t} \mathrm{ha}^{-1}\right)$. Harvest index which measures the productivity of the plant was derived by taking the ratio of the economic yield or the grains to the biological yield. Both the grains and the herbage of 3 sample plants from each treatment were oven-dried at $70^{\circ} \mathrm{C}$ for 72 hours before weighing.

\section{Data Analysis}

The consolidated data were analyzed using SAS version 6.02 and the significant treatments were compared using Tukey's Studentized Range (HSD) at Alpha 0.05 . 
Ratilla et al.

\section{Meteorological Data}

Total weekly rainfall ( $\mathrm{mm}$ ) and average daily minimum and maximum air temperature $\left({ }^{\circ} \mathrm{C}\right)$ throughout the duration of the study were obtained from the PAGASA Station in VSU, Visca, Baybay City Leyte.

\section{RESULTS AND DISCUSSION}

\section{Meteorological Data and General Observation}

Table 1 shows the total weekly rainfall and daily temperature (maximum and minimum) during the entire period of the experiment. During the dry season cropping, $\left(1^{\text {st }} \mathrm{crop}\right)$ the total weekly rainfall ranged from $0 \mathrm{~mm}$ to $13.2 \mathrm{~mm}$ or a total of $49 \mathrm{~mm}$ throughout the cropping period while the average daily temperature ranged from $23.0{ }^{\circ} \mathrm{C}$ to $30.1{ }^{\circ} \mathrm{C}$ (minimum) and $30.0{ }^{\circ} \mathrm{C}$ to $30.7{ }^{\circ} \mathrm{C}$ (maximum). Escalada (1996) stated that water consumption of corn ranges from 304.5 to $367.5 \mathrm{~mm}$ per cropping. This indicates that water was scarce in the site during the cropping period. The limited amount of water caused the failure of some seeds to germinate thus watering and replanting activities were employed. Obviously, plant growth and development during the first cropping were greatly affected as manifested by stunted plants and low yield. Yellowing of leaves was first noticed in the untreated control plots and in those treated with vermicast and chicken litter alone. However, those that received organic fertilizer combined with 45-30-30 kg N, $\mathrm{P}_{2} \mathrm{O}_{5}, \mathrm{~K}_{2} \mathrm{O}$ ha ${ }^{-1}$ from inorganic fertilizers showed vigorous growth with greener leaves especially during the second cropping. No control measures were employed throughout the duration of the study since the degree of damage due to pests was very minimal.

\section{Chemical and Physical Properties of Soil and the Applied Organic Fertilizers}

Initial soil analysis showed that the experimental area had an average bulk density value of 1.08 , $\mathrm{pH}$ value of $4.8,1.66 \%$ organic carbon, $0.21 \% \mathrm{~N}$, $0.74 \mathrm{mg} \mathrm{kg}^{-1}$ available phosphorus and $81.58 \mathrm{mg} \mathrm{kg}^{-1}$ extractable potassium (Table 2). These indicate that the study site was very strongly acidic, with very low organic matter, and low nitrogen, phosphorus and potassium contents (Landon 1991). Soil analyses after the first cropping revealed 
that there was only a very slight increase in the abovementioned parameters relative to the initial analysis Moreover, no significant variation among treatments were noted on the above chemical soil parameters as well as on the bulk density which means that values obtained were more or less the same.

Table 1. Total weekly rainfall $(\mathrm{mm})$ and average daily air temperature $\left({ }^{0} \mathrm{C}\right.$ minimum and maximum) throughout the duration of the study from March 1 to December 16, 2013 obtained from PAGASA Station, VSU, Visca, Baybay City, Leyte for the two cropping periods

\begin{tabular}{|c|c|c|c|}
\hline \multirow{2}{*}{$\begin{array}{r}\text { Weeks } \\
\mathbf{1}^{\text {st }} \text { Cropping } \\
\end{array}$} & \multirow[t]{2}{*}{ Rainfall (mm) } & \multicolumn{2}{|c|}{ Temperature $\left({ }^{0} \mathrm{C}\right)$} \\
\hline & & Maximum & Minimum \\
\hline 1 (March 1-11) & 8.4 & 31.4 & 27.8 \\
\hline 2 (March 12-18) & 0.7 & 30.5 & 23.7 \\
\hline 3 (March 19-25) & 1.2 & 30.5 & 23.3 \\
\hline 4 (March 26-April 1) & 4.6 & 30.2 & 23.5 \\
\hline 5 (April 2-8) & 2.7 & 30.6 & 23.7 \\
\hline 6 (April 9-15) & 0.3 & 30.4 & 23.8 \\
\hline 7 (April 16-22) & 3.8 & 30.0 & 23.2 \\
\hline 8 (April 23-April 29) & 0.0 & 31.2 & 24.1 \\
\hline 9 (April 30-May 6) & 0.2 & 31.3 & 24.1 \\
\hline 10 (May 7-May 13) & 6.2 & 30.3 & 23.3 \\
\hline 11 (May 14-20) & 0.0 & 30.7 & 23.8 \\
\hline 12 (May 21-27) & 1.3 & 30.0 & 23.0 \\
\hline 13 (May 28-June 3) & 0.8 & 30.3 & 23.4 \\
\hline 14 (June 4-10) & 5.6 & 30.1 & 23.2 \\
\hline 15 (June 11-17) & 13.2 & 30.1 & 23.1 \\
\hline TOTAL/MEAN & 49.00 & $456.30 /$ & $359.30 /$ \\
\hline \multicolumn{4}{|l|}{$2^{\text {nd }}$ Cropping } \\
\hline 1 (August 13-19) & 067.2 & 31.3 & 24.3 \\
\hline 2 (August 20-26) & 196.2 & 31.1 & 24.0 \\
\hline 3 (August 27-Sept 2) & 000.5 & 31.9 & 25.0 \\
\hline 4 (Sept 3-9) & 028.8 & 31.3 & 24.3 \\
\hline 5 (Sept 10-16) & 055.4 & 31.4 & 24.5 \\
\hline 6 (Sept 17- 23) & 000.5 & 31.0 & 24.0 \\
\hline 7 (Sept 24 - 30) & 088.9 & 31.0 & 24.0 \\
\hline 8 (Oct $1-7)$ & 283.3 & 31.1 & 23.9 \\
\hline $9($ Oct $8-14)$ & 013.6 & 31.5 & 24.5 \\
\hline $10($ Oct $15-21)$ & 036.0 & 31.5 & 24.7 \\
\hline 11 (Oct $22-28)$ & 045.8 & 31.3 & 24.4 \\
\hline $12($ Oct $29-$ Nov 4$)$ & 068.5 & 31.6 & 24.6 \\
\hline 13 (Nov $5-11)$ & 119.1 & ---- & ---- \\
\hline 14 (Nov $12-18$ ) & 056.8 & ----- & ----- \\
\hline $15($ Nov $19-25)$ & 013.2 & ----- & ----- \\
\hline 16 (Nov $26-\operatorname{Dec} 2)$ & 015.6 & ----- & ----- \\
\hline $17(\operatorname{Dec} 3-9)$ & 000.5 & 29.2 & 25.1 \\
\hline 18 (Dec $10-16)$ & 065.4 & 30.8 & 24.3 \\
\hline TOTAL/MEAN & 1155.3 & $436.0 / 31.1$ & $341.6 / 24.4$ \\
\hline
\end{tabular}


Ratilla et al.

Table 2. Bulk density and soil chemical properties before and after harvest of corn as influenced by the application of organic-based fertilizers in climate change vulnerable uplands of Inopacan Leyte

\begin{tabular}{|c|c|c|c|c|c|c|}
\hline Treatments & $\begin{array}{c}\text { Bulk } \\
\text { Density } \\
\left(D_{b}\right)\end{array}$ & $\begin{array}{c}\text { Soil pH } \\
(1: 2.5)\end{array}$ & $\begin{array}{c}\text { Organic } \\
\text { Carbon } \\
(\%)\end{array}$ & $\begin{array}{c}\text { Available } \\
\mathrm{N}(\%)\end{array}$ & $\begin{array}{l}\text { Available } \\
\quad \mathrm{P} \\
\text { (mg } / \mathrm{kg}^{-1} \\
\text { soil) }\end{array}$ & $\begin{array}{c}\text { Extractable } \\
\mathrm{K} \\
\left(\mathrm{mg} / \mathrm{kg}^{-1}\right. \\
\text { soil) }\end{array}$ \\
\hline \multicolumn{7}{|c|}{ Initial Analysis } \\
\hline & 1.08 & 4.80 & 1.67 & 0.21 & 0.74 & 81.58 \\
\hline \multicolumn{7}{|c|}{ After $1^{\text {st }}$ Cropping } \\
\hline $\mathrm{T}_{0}$ & 0.96 & 5.10 & 2.17 & 0.20 & 0.84 & 61.15 \\
\hline $\mathrm{T}_{1}$ & 0.98 & 4.93 & 2.25 & 0.25 & 0.79 & 70.13 \\
\hline $\mathrm{T}_{2}$ & 0.93 & 5.10 & 2.23 & 0.27 & 0.96 & 85.45 \\
\hline $\mathrm{T}_{3}$ & 0.96 & 5.30 & 2.09 & 0.25 & 1.01 & 71.58 \\
\hline $\mathrm{T}_{4}$ & 1.00 & 5.20 & 2.29 & 0.27 & 1.21 & 95.83 \\
\hline $\mathrm{T}_{5}$ & 0.92 & 5.10 & 2.03 & 0.24 & 0.89 & 71.90 \\
\hline $\mathrm{T}_{6}$ & 0.99 & 5.13 & 1.98 & 0.24 & 0.72 & 73.55 \\
\hline Mean & 0.96 & 5.12 & 2.15 & 0.25 & 0.92 & 75.66 \\
\hline C.V. & 5.63 & 3.15 & 12.36 & 22.95 & 24.73 & - \\
\hline \multicolumn{7}{|c|}{ After $2^{\text {nd }}$ Cropping } \\
\hline $\mathrm{T}_{0}$ & 1.28 & 5.08 & 1.71 & 0.24 & $1.60 \mathrm{c}$ & $93.36 \mathrm{~b}$ \\
\hline $\mathrm{T}_{1}$ & 1.37 & 4.94 & 1.91 & 0.28 & $1.88 \mathrm{bc}$ & $98.60 \mathrm{~b}$ \\
\hline $\mathrm{T}_{2}$ & 1.32 & 4.92 & 1.80 & 0.27 & $2.21 \mathrm{bc}$ & $102.96 \mathrm{ab}$ \\
\hline $\mathrm{T}_{3}$ & 1.36 & 5.18 & 2.02 & 0.28 & $11.04 \mathrm{a}$ & $188.72 \mathrm{a}$ \\
\hline $\mathrm{T}_{4}$ & 1.35 & 5.10 & 1.95 & 0.27 & $4.61 \mathrm{~b}$ & $165.38 \mathrm{ab}$ \\
\hline $\mathrm{T}_{5}$ & 1.30 & 5.02 & 1.89 & 0.25 & $1.68 \mathrm{c}$ & $103.11 \mathrm{ab}$ \\
\hline $\mathrm{T}_{6}$ & 1.34 & 4.93 & 2.01 & 0.27 & $2.36 \mathrm{bc}$ & $111.89 \mathrm{ab}$ \\
\hline Mean & 1.33 & 5.02 & 1.90 & 0.26 & 3.63 & 123.43 \\
\hline C.V. & 3.58 & 3.44 & 9.21 & 13.72 & 28.26 & 25.17 \\
\hline
\end{tabular}

$\mathrm{T}_{0}=$ Control $(0-0-0), \mathrm{T}_{1}=1 \mathrm{t} \mathrm{ha}^{-1}$ evans $+45-30-30 \mathrm{~kg} \mathrm{~N}_{2} \mathrm{P}_{2} \mathrm{O}_{5}, \mathrm{~K}_{2} \mathrm{O} \mathrm{ha}^{-1,} \mathrm{~T}_{2}=1 \mathrm{t} \mathrm{ha}^{-1}$ wellgrow $+45-30-30 \mathrm{~kg} \mathrm{~N}, \mathrm{P}_{2} \mathrm{O}_{5}, \mathrm{~K}_{2} \mathrm{O}$ ha $^{-1}, \mathrm{~T}_{3}=15 \mathrm{tha}^{-1}$ chicken litter alone, $\mathrm{T}_{4}=10 \mathrm{t} \mathrm{ha}^{-1}$ Chicken litter + 45-30-30 kg N, $\mathrm{P}_{2} \mathrm{O}_{5}, \mathrm{~K}_{2} \mathrm{O}$ ha $^{-1}$. $\mathrm{T}_{5}=15 \mathrm{t}$ havermicast alone, $\mathrm{T}_{6}=10 \mathrm{t} \mathrm{ha}^{-1}$ vermicast $+45-30-30$ $\mathrm{kg} \mathrm{N}, \mathrm{P}_{2} \mathrm{O}_{5}, \mathrm{~K}_{2} \mathrm{O}$ ha $^{-1}$

Similarly after the second cropping, most of the chemical soil parameters were not significantly affected by the treatments except for available $\mathrm{P}$ and exchangeable $\mathrm{K}$. The latter two soil parameters were increased by 4.88 and 1.51 times, respectively relative to the initial determination. Plots applied with $15 \mathrm{t}$ chicken litter ha ${ }^{-1}$ alone $\left(\mathrm{T}_{3}\right)$ had 
markedly higher $\mathrm{P}$ than the rest of the treatments. This was followed by those with $10 \mathrm{t}$ chicken litter ha ${ }^{-1}+45-30-30 \mathrm{~kg} \mathrm{~N}, \mathrm{P}_{2} \mathrm{O}_{5}, \mathrm{~K}_{2} \mathrm{O}$ ha ${ }^{-1}$ and those with other organic-based fertilizer sources. The lowest $\mathrm{P}$ was observed in the untreated control plots and those applied with vermicast alone. In the case of exchangeable $\mathrm{K}$, significantly higher values were also noted in plots with chicken litter applied alone or in combination with inorganic fertilizers. These values were comparable with those applied with vermicast and wellgrow. The least exchangeable $\mathrm{K}$ was noted in the control plots and those applied with Evans. It should be noted however, that despite such increment in $\mathrm{P}$ and $\mathrm{K}$ values after the second cropping as compared to the initial analysis, such increase was not high enough to support plant growth. There is still a need to supplement organic with inorganic fertilizers to enhance the productivity of this highly acidic marginal area.

Chemical analysis of organic-based fertilizers (Table 3) revealed that Wellgrow was the most alkaline (pH 8.17) while Evans was the most acidic ( $\mathrm{pH}$ 4.66). Vermicast and chicken litter had a near neutral $\mathrm{pH}$ of 6.40 and 6.98, respectively. Evans had the highest organic C (49.44\%) and total N $(4.26 \%)$ contents, but it had the lowest $\mathrm{K}(0.23 \%)$. Chicken litter contained the highest P (0.46\%) while Vermicast had the lowest $(0.25 \%)$. The analyses indicate that the organic materials varies in nutrient contents and their capacity to supply nutrients to crops. Water availability during the first cropping was also very limited which had greatly affected further decomposition and dissolution of nutrients for plant uptake.

Table 3. Chemical analysis of the different organic-based fertilizers used in the study

\begin{tabular}{lccccc}
\hline \multicolumn{1}{c}{ Samples } & $\mathrm{pH}$ & OC $(\%)$ & Total N (\%) & Total P (\%) & Total K (\%) \\
\hline Vermicast & 6.40 & 29.16 & 2.65 & 0.25 & 0.91 \\
Evans & 4.66 & 49.44 & 4.26 & 0.46 & 0.23 \\
Wellgrow & 8.17 & 34.67 & 2.36 & 0.36 & 2.70 \\
Chicken litter & 6.98 & 19.61 & 2.80 & 0.49 & 2.41 \\
\hline
\end{tabular}

\section{Agronomic Characteristics}

Significant differences were noted in almost all agronomic characters of corn in both cropping periods as influenced by the different treatments. Application of $10 \mathrm{t} \mathrm{ha}^{-1}$ chicken litter + 45-30-30 kg N, $\mathrm{P}_{2} \mathrm{O}_{5}, \mathrm{~K}_{2} \mathrm{O} \mathrm{ha}^{-1}$ (T4) significantly promoted early tasseling, silking and thus maturity of corn in the first cropping (Figure 1). The untreated control and those 
supplied with Evans $\left(1 \mathrm{t} \mathrm{ha}^{-1}+30-30-30 \mathrm{~kg} \mathrm{~N}, \mathrm{P}_{2} \mathrm{O}_{5}, \mathrm{~K}_{2} \mathrm{O} \mathrm{ha}^{-1}\right)$ and $15 \mathrm{t} \mathrm{ha}^{-1}$ Vermicast alone exhibited delayed tasseling, silking and maturity of plants. A similar trend on tasseling and maturity was observed in the second cropping (Figure 2). Plants applied with $10 \mathrm{t} \mathrm{ha}^{-1}$ of either chicken litter or vermicast supplemented with inorganic fertilizer tasseled and matured significantly earlier than those applied with organic fertilizers solely even at a higher rate. This shows that the readily available nutrients in inorganic fertilizers when used as supplement to organic materials can provide a good head start and thus promote growth and enhance completion of crop's life cycle.

Likewise, application of $10 \mathrm{tha}^{-1}$ chicken litter $+45-30-30 \mathrm{~kg} \mathrm{~N}, \mathrm{P}_{2} \mathrm{O}_{5}$, $\mathrm{K}_{2} \mathrm{O}$ ha $^{-1}$ markedly enhanced plant height and leaf area indices which consequently led to heavier fresh stover yields (Figures 3 and 5, respectively) of corn. But in most cases comparable response was noted in plants applied with $10 \mathrm{t} \mathrm{ha}^{-1}$ Vermicast + 45-30-30 kg N, $\mathrm{P}_{2} \mathrm{O}_{5}, \mathrm{~K}_{2} \mathrm{O}$ ha $^{-1}$. Biweekly plant height of corn applied with combined organic from either chicken litter or vermicast + half of the recommended rate (45-30-30 kg ha ${ }^{1}$ ) of inorganic fertilizers were consistently taller in all gathering periods. The least were observed on the untreated control $\left(\mathrm{T}_{0}\right)$ and those with Vermicast $\left(\mathrm{T}_{5}\right)$ alone and Evans $+30-30-30 \mathrm{~kg} \mathrm{~N}, \mathrm{P}_{2} \mathrm{O}_{5}, \mathrm{~K}_{2} \mathrm{O}$ ha $^{-1}\left(\mathrm{~T}_{1}\right)$. However, in the second cropping, significantly taller plants (Figure 4) were produced with lone vermicast application comparable to those applied with combined organic plus inorganic fertilizer. The untreated control plants were consistently the shortest in all gathering periods. The high amount and early release of nutrients particularly nitrogen from either inorganic or organic fertilizers contributed to this favorable vegetative growth of crops. Vermicast applied alone at 15 tons ha ${ }^{-1}$ failed to promote vigorous growth of corn in the first cropping despite its high nutrient content due to lack of moisture. This means that water availability is very important in making nutrients become available especially from organic fertilizers. Furthermore, under marginal areas where $\mathrm{N}$ is very low, the need for supplemental inorganic fertilizer is seen to be necessary for a faster availability of nutrients needed for growth.

Brady and Weil (2002) stressed that plants supplied with inorganic fertilizer grew vigorously because of readily available nutrients to support growth and development of crops. The findings of the study conformed with the above statement that the readily available nutrients provided by inorganic fertilizers led to the development of the tallest plants in $\mathrm{T}_{4} \mathrm{C} 10 \mathrm{t}$ ha ${ }^{-1}$ chicken litter $+45-30-30 \mathrm{~kg} \mathrm{~N}, \mathrm{P}_{2} \mathrm{O}_{5}, \mathrm{~K}_{2} \mathrm{O}$ ha $^{-1}$ ) although the values were 
comparable to the heights of the plants applied with $10 \mathrm{tha}^{-1}$ Vermicast + 45-30-30 kg N, $\mathrm{P}_{2} \mathrm{O}_{5}, \mathrm{~K}_{2} \mathrm{O} \mathrm{ha}^{-1}\left(\mathrm{~T}_{6}\right)$ and $1 \mathrm{t} \mathrm{ha}^{-1}$ Wellgrow $+30-30-30 \mathrm{~kg} \mathrm{~N}$, $\mathrm{P}_{2} \mathrm{O}_{5}, \mathrm{~K}_{2} \mathrm{O}$ ha $^{-1}\left(\mathrm{~T}_{2}\right)$. The control plants $\left(\mathrm{T}_{0}\right)$ aside from being the shortest, had the lightest stover yields in the second cropping (Fig. 6) though comparable with those supplied with Evans + 45-30-30 kg N, $\mathrm{P}_{2} \mathrm{O}_{5}, \mathrm{~K}_{2} \mathrm{O}$ ha ${ }^{-1}$ $\left(\mathrm{T}_{1}\right)$. These results further suggest that in marginal uplands where the soil is generally infertile and strongly acidic, a good head start of crops which can be achieved through the application of supplemental inorganic fertilizer.

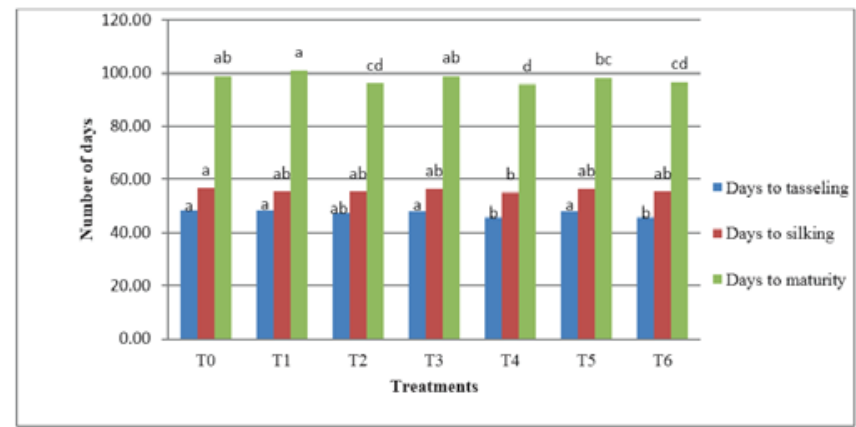

Fig. 1. Days from seeding to tasselling, silking and maturity of corn as influenced by the application of various organic-based fertilizers in climate change vulnerable marginal uplands of Inopacan, Leyte ( $1^{\text {st }}$ cropping); $\mathrm{T}_{0}=$ control $(0-0-0), \mathrm{T}_{1}=1 \mathrm{t} \mathrm{ha}^{-1}$ evans $+30-30-30 \mathrm{~kg} \mathrm{~N}, \mathrm{P}_{2} \mathrm{O}_{5}, \mathrm{~K}_{2} \mathrm{O}$ ha, $\mathrm{T}_{2}=1 \mathrm{t} \mathrm{ha}^{-1}$ wellgrow $+30-30-30 \mathrm{~kg} \mathrm{~N}, \mathrm{P}_{2} \mathrm{O}_{5}, \mathrm{~K}_{2} \mathrm{O}$ ha $^{-1}, \mathrm{~T}_{3}=15 \mathrm{t} \mathrm{ha}^{-1}$ chicken litter alone, $\mathrm{T}_{4}=10 \mathrm{t}$ $\mathrm{ha}^{-1}$ Chicken litter $+45-30-30 \mathrm{~kg} \mathrm{~N}, \mathrm{P}_{2} \mathrm{O}_{5}, \mathrm{~K}_{2} \mathrm{O} \mathrm{ha}^{-1}, \mathrm{~T}_{5}=15 \mathrm{tha}^{-1}$ vermicast alone, $\mathrm{T}_{6}=10$ tha vermicast $+45-30-30 \mathrm{~kg} \mathrm{~N}_{2} \mathrm{P}_{2} \mathrm{O}_{5}, \mathrm{~K}_{2} \mathrm{O} \mathrm{ha}^{-1}$

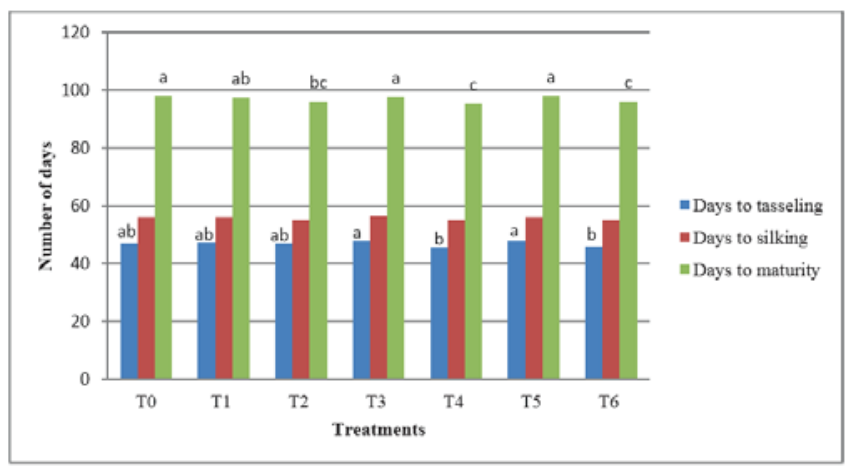

Fig. 2. Days from seeding to tasselling, silking and maturity of corn as influenced by the application of various organic-based fertilizers in climate change vulnerable marginal uplands of Inopacan, Leyte $\left(2^{\text {nd }}\right.$ cropping); $\mathrm{T}_{0}=\operatorname{control}(0-0-0), \mathrm{T}_{1}=1 \mathrm{t} \mathrm{ha}^{-1}$ evans $+45-$ 30-30 kg N, $\mathrm{P}_{2} \mathrm{O}_{5}, \mathrm{~K}_{2} \mathrm{O}$ ha, $\mathrm{T}_{2}=1 \mathrm{tha}^{-1}$ wellgrow $+45-30-30 \mathrm{~kg} \mathrm{~N}, \mathrm{P}_{2} \mathrm{O}_{5}, \mathrm{~K}_{2} \mathrm{O}$ ha $^{-1}, \mathrm{~T}_{3}=15 \mathrm{t} \mathrm{ha}^{-1}$ chicken litter alone, $\mathrm{T}_{4}=10 \mathrm{t} \mathrm{ha}^{-1}$ chicken litter $+45-30-30 \mathrm{~kg} \mathrm{~N}, \mathrm{P}_{2} \mathrm{O}_{5} \mathrm{~K}_{2} \mathrm{O} \mathrm{ha}^{-1}, \mathrm{~T}_{5}=15 \mathrm{t} \mathrm{ha}^{-1}$ vermicastalone, $\mathrm{T}_{6}=10$ tha $\mathrm{T}^{-1}$ vermicast $+45-30-30 \mathrm{~kg} \mathrm{~N}, \mathrm{P}_{2} \mathrm{O}_{5}, \mathrm{~K}_{2} \mathrm{O} \mathrm{ha}^{-1}$ 


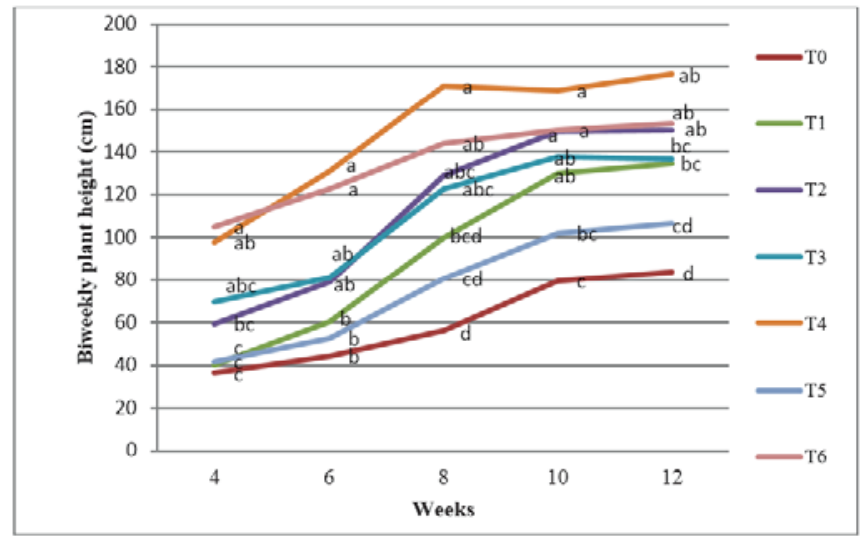

Fig. 3. Biweekly plant height of corn as influenced by the application of various organic-based fertilizers in climate change vulnerable marginal uplands of Inopacan, Leyte $\left(1^{\text {st }}\right.$ cropping). Where: $\mathrm{T}_{0}=$ control $(0-0-0), \mathrm{T}_{1}=1 \mathrm{t} \mathrm{ha}^{-1}$ evans $+30-30-30 \mathrm{~kg} \mathrm{~N}, \mathrm{P}_{2} \mathrm{O}_{5}, \mathrm{~K}_{2} \mathrm{O}$ ha, $\mathrm{T}_{2}=1 \mathrm{t} \mathrm{ha}^{-1}$ wellgrow $+30-30-30 \mathrm{~kg} \mathrm{~N}, \mathrm{P}_{2} \mathrm{O}_{5}, \mathrm{~K}_{2} \mathrm{O} \mathrm{ha}^{-1}, \mathrm{~T}_{3}=15 \mathrm{tha}^{-1}$ chicken litter alone, $\mathrm{T}_{4}=10$ tha ${ }^{-1}$ chicken litter $+45-30-30 \mathrm{~kg} \mathrm{~N}, \mathrm{P}_{2} \mathrm{O}_{5}, \mathrm{~K}_{2} \mathrm{O} \mathrm{ha}^{-1}, \mathrm{~T}_{5}=15 \mathrm{t} \mathrm{ha}^{-1}$ vermicast alone, $\mathrm{T}_{6}=10 \mathrm{t} \mathrm{ha}^{-1}$ vermicast + 45-30-30 $\mathrm{kg} \mathrm{N}, \mathrm{P}_{2} \mathrm{O}_{5}, \mathrm{~K}_{2} \mathrm{O} \mathrm{ha}^{-1}$

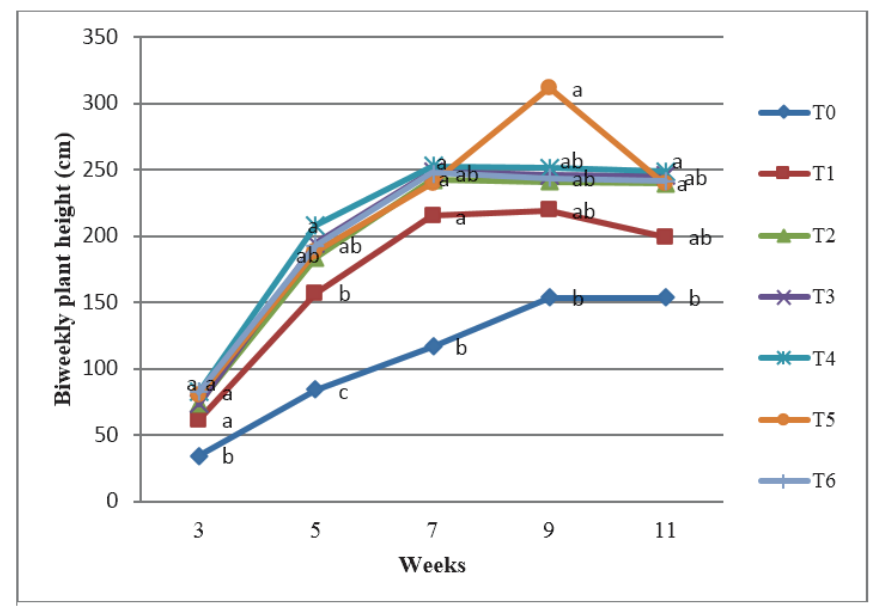

Fig. 4. Biweekly plant height of corn as influenced by the application of various organic-based fertilizers in climate change vulnerable marginal uplands of Inopacan, Leyte $\left(2^{\text {nd }}\right.$ cropping). Where: $\mathrm{T}_{0}=$ control $(0-0-0), \mathrm{T}_{1}=1 \mathrm{t} \mathrm{ha}^{-1}$ evans $+30-30-30 \mathrm{~kg} \mathrm{~N}, \mathrm{P}_{2} \mathrm{O}_{5}, \mathrm{~K}_{2} \mathrm{O}$ ha, $\mathrm{T}_{2}=1 \mathrm{t} \mathrm{ha}^{-1}$ wellgrow $+45-30-30 \mathrm{~kg} \mathrm{~N}, \mathrm{P}_{2} \mathrm{O}_{5}, \mathrm{~K}_{2} \mathrm{O} \mathrm{ha}^{-1}, \mathrm{~T}_{3}=15 \mathrm{tha}^{-1}$ chicken litter alone, $\mathrm{T}_{4}=10$ t ha ${ }^{-1}$ chicken litter $+45-30-30 \mathrm{~kg} \mathrm{~N}_{2} \mathrm{P}_{2} \mathrm{O}_{5}, \mathrm{~K}_{2} \mathrm{O} \mathrm{ha}^{-1}, \mathrm{~T}_{5}=15 \mathrm{t} \mathrm{ha}^{-1}$ vermicast alone, $\mathrm{T}_{6}=10$ tha $^{-1}$ vermicast $+45-30-30 \mathrm{~kg} \mathrm{~N}, \mathrm{P}_{2} \mathrm{O}_{5}, \mathrm{~K}_{2} \mathrm{O} \mathrm{ha}^{-1}$ 


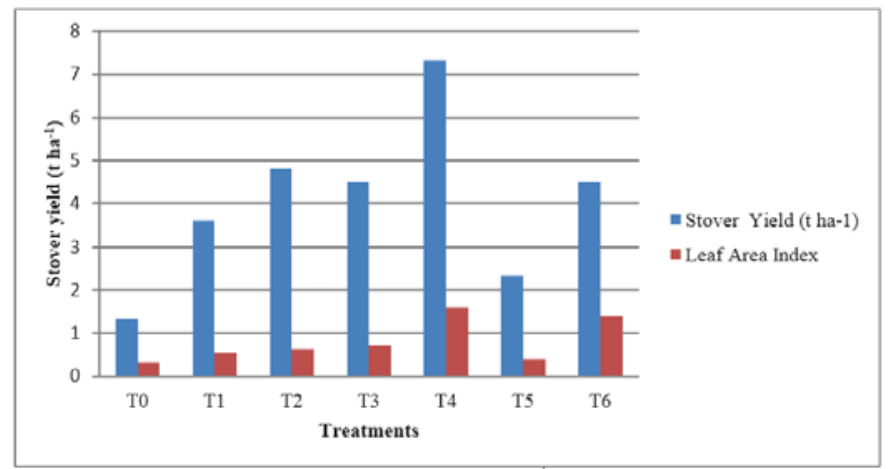

Fig. 5. Fresh stover yield and leaf area index of corn as influenced by the application of various organic- based fertilizers in climate change vulnerable marginal uplands of Inopacan, Leyte ( $1^{\text {st }}$ cropping); $\mathrm{T}_{0}=$ control $(0-0-0), \mathrm{T}_{1}=1 \mathrm{tha}^{-1}$ evans $+30-30-30 \mathrm{~kg} \mathrm{~N}, \mathrm{P}_{2} \mathrm{O}_{5}, \mathrm{~K}_{2} \mathrm{O}$ ha, $\mathrm{T}_{2}=1 \mathrm{tha}^{-1}$ wellgrow $+30-30-30 \mathrm{~kg} \mathrm{~N}, \mathrm{P}_{2} \mathrm{O}_{5}, \mathrm{~K}_{2} \mathrm{O} \mathrm{ha}^{-1}, \mathrm{~T}_{3}=15 \mathrm{t} \mathrm{ha}^{-1}$ chicken litter alone, $\mathrm{T}_{4}=10 \mathrm{t}$ ha $^{-1}$ chicken litter $+45-30-30 \mathrm{~kg} \mathrm{~N}, \mathrm{P}_{2} \mathrm{O}_{5}, \mathrm{~K}_{2} \mathrm{O}$ ha $^{-1}, \mathrm{~T}_{5}=15 \mathrm{t} \mathrm{ha}^{-1}$ vermicast alone, $\mathrm{T}_{6}=10 \mathrm{t} \mathrm{ha}^{-1}$ vermicast $+45-30-30 \mathrm{~kg} \mathrm{~N}, \mathrm{P}_{2} \mathrm{O}_{5}, \mathrm{~K}_{2} \mathrm{Oha}^{-1}$

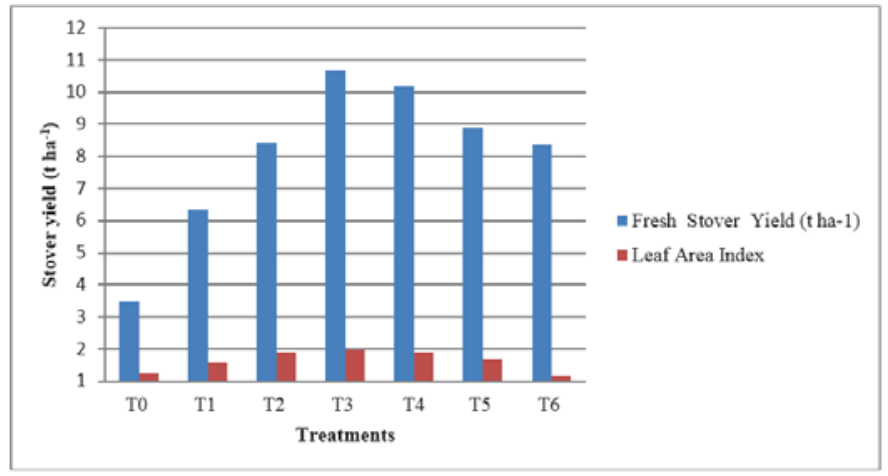

Fig. 6. Fresh stover yield and leaf area index and of corn as influenced by the application of various organic- based fertilizers in climate change vulnerable marginal uplands of Inopacan, Leyte $\left(2^{\text {nd }}\right.$ cropping); $\mathrm{T}_{0}=$ control $(0-0-0), \mathrm{T}_{1}=1 \mathrm{t} \mathrm{ha}^{-1}$ evans $+30-30-30 \mathrm{~kg} \mathrm{~N}$, $\mathrm{P}_{2} \mathrm{O}_{5}, \mathrm{~K}_{2} \mathrm{O}$ ha, $\mathrm{T}_{2}=1$ t ha $^{-1}$ wellgrow $+45-30-30 \mathrm{~kg} \mathrm{~N}, \mathrm{P}_{2} \mathrm{O}_{5}, \mathrm{~K}_{2} \mathrm{O}$ ha $^{-1}, \mathrm{~T}_{3}=15$ t ha ${ }^{-1}$ chicken litter alone, $\mathrm{T}_{4}=10$ tha $^{-1}$ chicken litter $+45-30-30 \mathrm{~kg} \mathrm{~N}, \mathrm{P}_{2} \mathrm{O}_{5}, \mathrm{~K}_{2} \mathrm{O} \mathrm{ha}^{-1}, \mathrm{~T}_{5}=15$ tha ${ }^{-1}$ vermicast alone, $\mathrm{T}_{6}=10$ tha $^{-1}$ vermicast $+45-30-30 \mathrm{~kg} \mathrm{~N}, \mathrm{P}_{2} \mathrm{O}_{5}, \mathrm{~K}_{2} \mathrm{O} \mathrm{ha}^{-1}$

\section{Yield and Yield Components and Harvest Index}

Tables 4 and 5 show the yield and yield components, as well as the harvest index of corn as influenced by the application of different organicbased fertilizers during the first and second croppings. Results revealed that ear size, weight of 1000 seeds and grain yield were 
Ratilla et al.

significantly influenced by the treatments. Application of $10 \mathrm{t} \mathrm{ha}^{-1}$ chicken litter $+45-30-30 \mathrm{~kg} \mathrm{~N}, \mathrm{P}_{2} \mathrm{O}_{5}, \mathrm{~K}_{2} \mathrm{O} \mathrm{ha}^{-1}\left(\mathrm{~T}_{4}\right)$ consistently produced longer and bigger ears and had the heaviest grain weight which consequently led to higher grain yield. The better stand of crops grown in this particular treatment subsequently supported its yield performance. The control plants however, obtained the smallest ear size and weight of 1000 seeds thus the lowest grain yield.

Plants applied with other sources of organic fertilizers which were applied alone or in combination with inorganic fertilizers had comparable yield components with $\mathrm{T}_{4}$. In terms of grain yield, they also followed $\mathrm{T}_{4}$ except for the lone application of $15 \mathrm{t} \mathrm{ha}^{-1}$ vermicast $\left(\mathrm{T}_{5}\right)$ which had a more or less similar yield compared with the untreated control. Increasing the rate of vermicast application to $15 \mathrm{t} \mathrm{ha}^{-1}$ did not cause any corresponding increase in growth and yield of corn but the performance remained comparably poor as with the untreated control. These findings generally suggest the need to integrate inorganic fertilizer supplementation especially this $\mathrm{N}$ fertilizers for this highly degraded area. This conforms to the findings of Ayeni and Adetunji (2008) that supplementing inorganic fertilizers to poultry manure increased availability and uptake of nutrients and thus the performance of maize. They added that organic fertilizers will act as chelate to micronutrients especially the acidic cations which could be abundant in this experimental site being highly acidic. With organic materials chelating acidic cations, toxicity of the latter is being reduced aside from improving the physical, chemical and biological properties of soil. This will probably lead to efficient crop production and soil conservation. But such a change in soil quality takes longer depending on the type of management imposed to the agroecosystem (Mazzoncini et al. 2010). Thus, under marginal areas, said benefits may not be immediately obtained after just one cropping. In the second cropping however, though seed weight was not significantly affected by the treatments, ear length and diameter greatly improved relative to the control (Table 5). This resulted in a markedly higher grain yield in treatment plots that received chicken litter or vermicast with or without inorganic supplements. Similarly, higher harvest indices were noted in these treatments indicating high efficiency in converting photosynthates into grains relative to the control. The control as well as those treated with Evans and Wellgrow plus inorganic fertilizers consistently produced lower grain yields. This implies that the rate of the aforementioned organic fertilizers which were supposed to be the manufacturer's recommendation ( 20 bags ha $^{-1}$ or 1 tha $^{-1}$ ) was relatively low 
under the condition of the study. There is a need to continue the croppings to further check not only on the crops' performance but also on soil improvement, sustainability and profitability of the treatments.

Table 3. Yield, yield components and harvest index of corn as influenced by the application of various organic-based fertilizers in climate change vulnerable marginal uplands of Inopacan, Leyte ( $1^{\text {st }}$ cropping-dry season).

\begin{tabular}{cccccc}
\hline Treatments & $\begin{array}{c}\text { Ear length } \\
(\mathrm{cm})\end{array}$ & $\begin{array}{c}\text { Ear diameter } \\
(\mathrm{cm})\end{array}$ & $\begin{array}{c}1000 \mathrm{seed} \\
\text { weight }(\mathrm{g})\end{array}$ & $\begin{array}{c}\text { Grain yield } \\
\left(\mathrm{t} \mathrm{ha}^{-1}\right)\end{array}$ & $\begin{array}{c}\text { Harvest } \\
\text { Index }\end{array}$ \\
\hline $\mathrm{T}_{0}$ & $2.54 \mathrm{c}$ & $1.20 \mathrm{~b}$ & $73.98 \mathrm{~b}$ & $0.06 \mathrm{c}$ & $0.08 \mathrm{~b}$ \\
$\mathrm{~T}_{1}$ & $6.63 \mathrm{abc}$ & $3.69 \mathrm{a}$ & $226.38 \mathrm{ab}$ & $1.06 \mathrm{~b}$ & $0.62 \mathrm{a}$ \\
$\mathrm{T}_{2}$ & $10.05 \mathrm{ab}$ & $4.13 \mathrm{a}$ & $239.51 \mathrm{a}$ & $1.48 \mathrm{~b}$ & $0.60 \mathrm{a}$ \\
$\mathrm{T}_{3}$ & $7.63 \mathrm{abc}$ & $3.93 \mathrm{a}$ & $226.58 \mathrm{a}$ & $1.15 \mathrm{~b}$ & $0.50 \mathrm{a}$ \\
$\mathrm{T}_{4}$ & $11.40 \mathrm{a}$ & $4.23 \mathrm{a}$ & $253.00 \mathrm{a}$ & $2.15 \mathrm{a}$ & $0.47 \mathrm{a}$ \\
$\mathrm{T}_{5}$ & $5.41 \mathrm{bc}$ & $3.23 \mathrm{ab}$ & $189.79 \mathrm{ab}$ & $0.21 \mathrm{c}$ & $0.41 \mathrm{a}$ \\
$\mathrm{T}_{6}$ & $8.30 \mathrm{abc}$ & $3.94 \mathrm{a}$ & $227.45 \mathrm{a}$ & $1.26 \mathrm{~b}$ & $0.54 \mathrm{a}$ \\
\hline Mean & 7.42 & 3.48 & 205.24 & 1.05 & 0.46 \\
C.V. $(\%)$ & 27.42 & 23.40 & 26.00 & 18.79 & 18.26 \\
\hline
\end{tabular}

Means followed by the same letter in a column are not significantly different at $5 \%$ level of significance based on Tukey's test. Where: $\mathrm{T}_{0}=$ Control $(0-0-0), \mathrm{T}_{1}=1 \mathrm{t} \mathrm{ha}^{-1}$ Evans $+30-30-30 \mathrm{~kg}$ $\mathrm{N}, \mathrm{P}_{2} \mathrm{O}_{5}, \mathrm{~K}_{2} \mathrm{O}$ ha, $\mathrm{T}_{2}=1 \mathrm{t}$ ha ${ }^{-1}$ Wellgrow $+30-30-30 \mathrm{~kg} \mathrm{~N}, \mathrm{P}_{2} \mathrm{O}_{5}, \mathrm{~K}_{2} \mathrm{O}$ ha $^{-1}, \mathrm{~T}_{3}=15 \mathrm{t} \mathrm{ha}^{-1}$ Chicken litter alone, $\mathrm{T}_{4}=10$ tha $^{-1}$ Chicken litter $+45-30-30 \mathrm{~kg} \mathrm{~N}, \mathrm{P}_{2} \mathrm{O}_{5}, \mathrm{~K}_{2} \mathrm{O} \mathrm{ha}^{-1}, \mathrm{~T}_{5}=15$ tha ${ }^{-1}$ Vermicast alone, $\mathrm{T}_{6}=10 \mathrm{t}$ $\mathrm{ha}^{-1}$ Vermicast $+45-30-30 \mathrm{~kg} \mathrm{~N}, \mathrm{P}_{2} \mathrm{O}_{5}, \mathrm{~K}_{2} \mathrm{Oha}^{-1}$

Table 4. Yield and yield components of corn as influenced by the application of organicbased fertilizers in climate change vulnerable marginal uplands of Inopacan, Leyte ( $2^{\text {nd }}$ cropping-wet season).

\begin{tabular}{cccccc}
\hline Treatments & $\begin{array}{c}\text { Ear Length } \\
(\mathrm{cm})\end{array}$ & $\begin{array}{c}\text { Ear diameter } \\
(\mathrm{cm})\end{array}$ & $\begin{array}{c}\text { 1000 seed } \\
\text { weight }(\mathrm{g})\end{array}$ & $\begin{array}{c}\text { Grain yield } \\
\left(\mathrm{t} \mathrm{ha}^{-1}\right)\end{array}$ & $\begin{array}{c}\text { Harvest } \\
\text { Index }\end{array}$ \\
\hline $\mathrm{T}_{0}$ & $8.57 \mathrm{~b}$ & $3.33 \mathrm{~b}$ & 197.48 & $0.58 \mathrm{~d}$ & $0.29 \mathrm{~b}$ \\
$\mathrm{~T}_{1}$ & $15.53 \mathrm{ab}$ & $4.16 \mathrm{ab}$ & 219.87 & $1.18 \mathrm{~cd}$ & $0.42 \mathrm{ab}$ \\
$\mathrm{T}_{2}$ & $14.96 \mathrm{ab}$ & $4.34 \mathrm{a}$ & 234.93 & $1.45 \mathrm{bcd}$ & $0.43 \mathrm{ab}$ \\
$\mathrm{T}_{3}$ & $16.07 \mathrm{a}$ & $4.53 \mathrm{a}$ & 246.60 & $2.22 \mathrm{abc}$ & $0.52 \mathrm{a}$ \\
$\mathrm{T}_{4}$ & $17.30 \mathrm{a}$ & $4.69 \mathrm{a}$ & 255.73 & $3.06 \mathrm{a}$ & $0.53 \mathrm{a}$ \\
$\mathrm{T}_{5}$ & $14.14 \mathrm{ab}$ & $4.10 \mathrm{ab}$ & 245.33 & $2.28 \mathrm{abc}$ & $0.42 \mathrm{ab}$ \\
$\mathrm{T}_{6}$ & $14.31 \mathrm{ab}$ & $4.46 \mathrm{a}$ & 243.23 & $2.45 \mathrm{ab}$ & $0.53 \mathrm{a}$ \\
\hline Mean & 14.41 & 4.23 & 234.74 & 1.89 & 0.45 \\
C.V. $(\%)$ & 17.93 & 8.36 & 11.21 & 21.92 & 13.72 \\
\hline
\end{tabular}

Means followed by the same letter in a column are not significantly different at $5 \%$ level of significance based on Tukey's test. Where: $\mathrm{T}_{0}=$ Control $(0-0-0), \mathrm{T}_{1}=1$ tha $^{-1}$ evans $+45-30-30 \mathrm{~kg} \mathrm{~N}, \mathrm{P}_{2} \mathrm{O}_{5}, \mathrm{~K}_{2} \mathrm{O}$ ha, $\mathrm{T}_{2}=1$ tha ${ }^{-1}$ wellgrow $+45-30-30 \mathrm{~kg} \mathrm{~N} \mathrm{P}_{2} \mathrm{O}_{5}, \mathrm{~K}_{2} \mathrm{O} \mathrm{ha}^{-1}, \mathrm{~T}_{3}=15 \mathrm{t} \mathrm{ha}^{-1}$ chicken litter alone, $\mathrm{T}_{4}=10 \mathrm{t} \mathrm{ha}^{-1}$ chicken litter $+45-30-30 \mathrm{~kg} \mathrm{~N}, \mathrm{P}_{2} \mathrm{O}_{5} \mathrm{~K}_{2} \mathrm{O} \mathrm{ha}^{-1}, \mathrm{~T}_{5}=15 \mathrm{tha}^{-1}$ vermicast alone, $\mathrm{T}_{6}=10$ tha ${ }^{-1}$ vermicast $+45-30-30 \mathrm{~kg} \mathrm{~N}, \mathrm{P}_{2} \mathrm{O}_{5}$, $\mathrm{K}_{2} \mathrm{Oha}^{-1}$ 
Ratilla et al.

\section{CONCLUSIONS}

Based on the results of the study, the following conclusions can be drawn:

1. The different organic-based fertilizers significantly affected most of the growth characteristics, yield and yield components, as well as harvest index of corn grown in the marginal uplands of Inopacan, Leyte.

2. Application of $10 \mathrm{t} \mathrm{ha}^{-1}$ chicken litter $+45-30-30 \mathrm{~kg} \mathrm{~N}, \mathrm{P}_{2} \mathrm{O}_{5}, \mathrm{~K}_{2} \mathrm{O} \mathrm{ha}^{-1}$ resulted in better performance of corn during both croppings and appeared the most promising fertilizer combination.

3. Soil analysis of the physical and chemical properties did not show significant differences among treatments except for a general increase in available $\mathrm{P}$ and exchangeable $\mathrm{K}$ after the second cropping. These parameters were generally higher with chicken litter applied alone or in combination with inorganic fertilizers.

\section{RECOMMENDATIONS}

There is a need to continue the study for more croppings to check the residual effects of the organic fertilizers in improving the soil properties and in enhancing crop productivity as well as the sustainability of the treatments. Despite the availability and affordable cost of organic inputs in the locality, cost and return analysis after at least three croppings need to be considered to determine its profitability.

\section{REFERENCES}

AGUILERA, E., L. LASSALETTA, A. S. COBENA, J. GARNIER and A. VALLEJO. 2013. The potential of organic fertilizers and water management to reduce $\mathrm{N} 2 \mathrm{O}$ emissions in Mediterranean climate cropping systems. A review. Agric, Ecosystems and Environment. 164: 32-52.

AYENI, L.S. and M.T. ADETUNJI. 2008. Integrated application of poultry manure and mineral fertilizer on soil chemical properties, nutrient uptake, yield and growth components of maize. Nature and Science. 1:60-67.

BRADY, N.C. and R.R. WEIL. 2002. The Nature and Properties of Soils. $13^{\text {th }}$ edition. Prentice Hall. Upper Saddle River, New Jersey 07458. 960pp. 
Evaluation of Organic-Based Fertilizers on Corn in Marginal Uplands

COSICO, W. 2005. Primer of Soil Science. University of the Philippines, Los Baños, Laguna, Philippines. 182pp.

LANDON, J.R. 1991. Booker Tropical Soil Manual. A hand book for soil survey and Agricultural Land Evaluation in the Tropics and Subtropics. Longman Scientific and Technical John Wiley and Sons, Inc. 605 Third Avenue, New York, NY 10158474 pp.

MAZZONCINI, M., S. CANALI, M. GIOVANNETTI, M. CASTAGNOLI, F. TITTARELLI, D. ANTICHI, R. NANNELLI, C. CRISTANI, and P. BARBERI. 2010. Comparison of organic and conventional stockless arable systems: A multidisciplinary approach to soil quality evaluation. Applied Soil Ecology. 44:124-132.

MULLER, A. 2009. Benefits of organic agriculture as climate change adaptation and mitigation strategy for developing countries. In: Environment for Development Discussion Paper Series. April 2009. EfD DP 09-09.

PERUMAL, K., K. PRAVEENA, V. STALIN and B. JANARTHANAM. 2006. Assessment of selected organic manures as plant growth hormones and their impact on the growth attributes of Alium cepa Lin. Current Science.http://www.biodynamic.net.au/biodynamic_research.htm.

QUIMBO, M.C., C.P. MAMARIL and K.L.S. TAFERE. 2014. Organic versus inorganic management on the yield and soil fertility of irrigated lowland rice. Annals of Tropical Research. 36(1):32-49.

SCILLABBA, N. EH. and M. LINDENLAUF. 2010. Organic agriculture and climate change. Renewable Agriculture and Food Systems: 25(2); 158169. 